\title{
Incorporation of the Effects of Volcanic Eruptions in Stochastic Precipitation Model in Watershed. Tungurahua Volcano Case in the River Watershed Ambato
}

\author{
Iván Ríos ${ }^{1}$, Abel Solera ${ }^{2}$ \\ ${ }^{1}$ Universidad Nacional de Chimborazo\&Riobamba-Ecuador \\ ${ }^{2}$ Universidad Politécnica de Valencia\&Valencia-España
}

\begin{abstract}
Studies have shown that the variability of precipitation depends primarily of climatic factors, wind, temperature, and atmospheric pressure, however in the past twenty years the continuous eruptive process of volcano Tungurahua has been a natural factor that contributed to the variability of precipitations in short term and to the extension of the watershed of Ambato River. To incorporate the effects of the eruptive process of a volcano over precipitations, initially the study zone was selected, the weather stations located within a $100 \mathrm{~km}$ radius from the volcano's location, and the sub periods for the study. An ARIMAX model is build, which consists of two components: the first one is a deterministic exogenous component; to estimate this component, it is necessary to determine the concentration of $\mathrm{SO}_{2}$ in air produced by the eruptive events over the watershed and its conintegration with the precipitation series is established.
\end{abstract}

Keywords: volcanic eruption, rainfall variability, Tungurahua

\section{Introduction}

In Ecuador, its climatic diversity, geography and availability of water resources is influenced by the presence of the Andes that is a determining factor in topography and climate in the three regions. According to the Geophysical Institute of the National Polytechnic within the mainland of Ecuador 84 volcanoes emerge, of which 60 are inactive or asleep, 16 are potentially active, five are active and 3 are in stage of eruption.

In the specific case of the Tungurahua volcano, it restarts its activity in 1993, after 80 years of rest. This natural phenomenon causes changes in rainfall patterns with significant increases in rainfall of $42.25 \%$ in December and significant decreases of $40.03 \%$ in September during the eruptive process [1].

Based on this information we can say that the potential risk of volcanic eruptions in the country is high and requires extensive research in various fields, including analysis of the effects of the eruptive process in other natural phenomena such as precipitation. Specifically in relation to this issue this methodology can become a contribution to integrate the effects of volcanic eruptions on stochastic models of precipitation in watersheds.

\section{Background}

Watersheds and micro-watersheds located throughout the territory of Ecuador, have a high degree of vulnerability and risk due to the presence of volcanoes with different levels of eruptive activity. In the last twenty years have made great efforts to identify and mitigate the impacts of a volcano eruption process has on human health and the agricultural industry mainly, but little or nothing is known about the impacts that cause eruptions on climate variability and change at the local level, or on the changes brought in precipitation patterns in the short term and at the level of a river watershed. This has prompted the current investigation.

The subject of this research was developed with the expectation to contribute methodologies to identify, analyze and incorporate amendments to the climatic variable precipitation micro-watershed level, in the short term, effects of a volcanic eruption, and generate information that becomes technical input to the planning and management of water systems.

Under these considerations, the importance of conducting studies and research on models that incorporate the effects of a volcanic eruption that technically demonstrate the presence of possible changes in precipitation patterns is evident, as well as the positive and negative impacts related to the eruption of a volcano micro-watershed level.

\section{Description of the study area}

The province of Tungurahua is located in the central area of Ecuador, with an approximate area of $3.335 \mathrm{~km}^{2}$, covers part of the Andean Valley and West and East Chain Mountain, which includes the Tungurahua volcano and the snowcapped Carihuairazo and Chimborazo [2].

The watershed of the Ambato River, located to the northeast of the province Figure 1, in the western chain mountain, with an extension of $1.317 \mathrm{~km}^{2}$, has an average temperature of $12.5{ }^{\circ} \mathrm{C}$, July records less rainfall with a mean value $48,00 \mathrm{~mm}$, while April with average values of $86,67 \mathrm{~mm}$ is the month of greatest precipitation [2]. 


\section{International Journal of Science and Research (IJSR) ISSN (Online): 2319-7064}

Index Copernicus Value (2013): 6.14 | Impact Factor (2014): 5.611

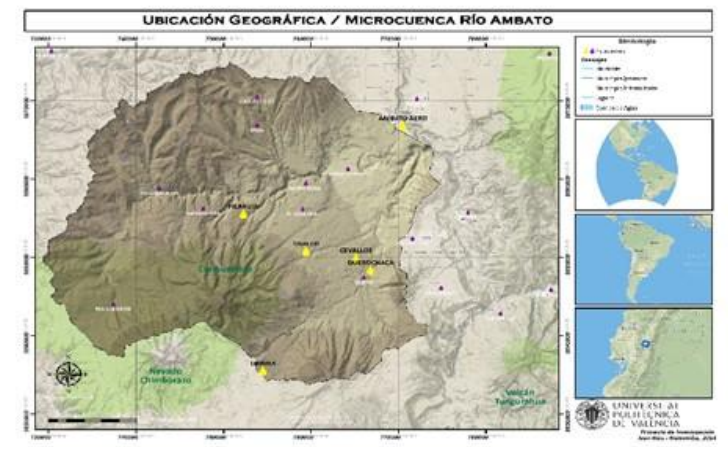

Figure 1: Geographical location Ambato River watershed

[1]

The Tungurahua volcano, located in the Cordillera of the Ecuadorian Andes on latitude $01^{\circ} 28^{\prime}$ south and longitude $78{ }^{\circ} 27^{\prime}$ west, is located $33 \mathrm{~km}$ southeast of the city of Ambato in the province of Tungurahua. It is an active volcano of 5.023 meters in elevation above the sea level, characterized by its conical shape, the large existing relief between its base and crater $(3.200 \mathrm{~m})$ and pronounced slopes on their flanks $\left(30^{\circ}-35^{\circ}\right)$ [3].

In August 1999, the volcano started an explosive eruptive period with alternating phases of high volcanic activity, characterized by strong emission of gas and ash, such as explosions, cannon and episodes of lava fountain, with low activity phases represented by weak steam emissions ash, and phases of complete tranquility.
The study and the methodology applied in this case through the monitoring data and records made in the five selected weather stations: The Ambato station, located northeast of the watershed at a distance of $32,73 \mathrm{~km}$ of the volcano Cevallos and Tisaleo the stations, east of the watershed at a distance of 23,40 km, 28,88 km and 21,31 km respectively volcano, the Pilahuin station, located in the center of the watershed at a distance of $37,57 \mathrm{~km}$ of the volcano, and Urbina station in the south of the watershed at a distance of $25,52 \mathrm{~km}$ of the volcano.

\section{Methodology}

An ARIMAX model [4], consisting of two components to incorporate the volcano eruption process and changes in precipitation time series is identified Equation (1): The first $Y v$ is a deterministic exogenous component which represents the disturbance due to the concentration of $\mathrm{SO}_{2}$ caused by the volcano's eruptive events and the second stochastic component $Y t$ and follows a model ARIMA [5]. To calculate $Y v$ is necessary to determine the existence of a cointegration of time series of precipitation and concentration of $\mathrm{SO}_{2}$ in the watershed.

$$
Z_{t}=Y_{t}+Y v
$$

To estimate the concentration of $\mathrm{SO}_{2}$ in the air, the eruptive style of the volcano and the index of explosiveness of volcanic eruptions (VEI) is identified. Geophysical data provided by Institutes. In Table 1 it can be seen that depending on (VEI) preliminary information on the volume of ash and the column height is obtained.

Table 1: The volcanic explosivity index[6]

\begin{tabular}{|c|c|c|c|c|c|c|c|c|c|}
\hline VEI index & 0 & 1 & 2 & 3 & 4 & 5 & 6 & 7 & 8 \\
\hline General Description & $\begin{array}{l}\text { No } \\
\text { explosive }\end{array}$ & Small & Moderate & $\begin{array}{c}\text { Moderate- } \\
\text { Large }\end{array}$ & Large & \multicolumn{4}{|c|}{ Very Large } \\
\hline $\begin{array}{l}\text { Qualitative } \\
\text { Description }\end{array}$ & S oft & Effusive & \multicolumn{2}{|c|}{ Explosive } & \multicolumn{4}{|c|}{ Cataclysm } & \\
\hline $\begin{array}{l}\text { Volvme of tephra } \\
\left(\mathrm{m}^{3}\right)\end{array}$ & $10^{4}$ & $10^{6}$ & $10^{7}$ & $10^{3}$ & $10^{\circ}$ & $10^{t 0}$ & $10^{\mathrm{th}}$ & $10^{12}$ & $10^{13}$ \\
\hline Colvmn height $(\mathrm{cm})$ & $<0,1$ & $0,1-1$ & $1-5$ & $3-15$ & $10-25$ & \multicolumn{4}{|c|}{$>25$} \\
\hline
\end{tabular}

The model sulfur monoxide concentration is developed under the premise that a step load of $\mathrm{SO}_{2}$ emitted by a volcano, it is a steady state solution mass balance and response time in a column of air affected. Equation (2) adapted simulation Euler's variable time period [7] using data from the study that is affected by the volcanic eruption arises.

$$
c_{i+1}=c_{i}+\left[\left(t_{i+1}-t_{i}\right) *\left[\frac{W_{t}}{V}-\left(K_{a}+\frac{v_{v} * A_{c} * F_{d w}}{V}+\frac{v_{d} * A_{c} * F_{d w}}{V}+K_{a b}\right)\right]\right]
$$

This procedure gives us values of $\mathrm{SO}_{2}$ concentration in $\mathrm{mg} / \mathrm{m} 3$ in each of the months from the start of the eruption process, whereby a time series of concentrations of $\mathrm{SO}_{2}$ is obtained. To determine whether the series are cointegrated apply the test of Engle-Granger cointegration [8] series residues are estimated by a regression and pass through the Dickey Fuller Increased [8]. If it meets the test then the series of precipitation and concentration of $\mathrm{SO}_{2}$ are cointegrated, therefore you can apply a linear regression
Equation (3), being $C_{v \mathrm{SO}_{2}}$ the concentration of $\mathrm{SO}_{2}$, a and b the slope and intercept respectively. Normality test JarqueBera residues apply, heterocedasticity test ARCH, and test Reset of the functional form test [9].

$Y_{v}=a * C_{v S O 2}+b(3)$

The $Y_{t}$ component is the result of a stochastic process ARIMA model, its estimate is summarized in three steps; model identification, parameter estimation model and model validation [10]. To identify model series be stationary in the broad sense, namely zero mean and constant variance, the model by comparing the sample autocorrelation functions obtained with the theoretical functions of ARMA models identified. Once you have chosen model (p, d, q), we proceed to estimate the autoregressive moving average parameters, which meet the conditions of stationarity, the sum of the coefficient values of each parameter must be $<\mid 1$ | and p-value $<5 \%$. The estimated model should adequately 


\section{International Journal of Science and Research (IJSR) \\ ISSN (Online): 2319-7064 \\ Index Copernicus Value (2013): 6.14 | Impact Factor (2014): 5.611}

represent the process generated comments and to validate the coefficients must comply with the conditions of stationarity and invertibility.

\section{Discussion}

The methodology is applied to the Tungurahua volcano eruption process, in the period 1990 to 2013 that reactivation occurs with a continuous emission of ash and gases, also with large explosive events from the year 1999, causing sharp increases in the amount of rainfall in the watershed of the Ambato River.

The concentration of $\mathrm{SO}_{2}$ in the eruptive process of the Tungurahua volcano is calculated in three areas of the watershed of the Ambato river, a Eulerian model with monthly time variations of the meteorological variables used and data from monthly charges of $\mathrm{SO}_{2}$ obtained in the Institute uses geophysical Ecuador. It is established that the content of sulfur oxide is uniformly mixed in the area of $1.317 \mathrm{~km}^{2}$ of the watershed, with an average height of 1,5 $\mathrm{km}$ above the crater of the volcano, where the main chemical reactions occur.

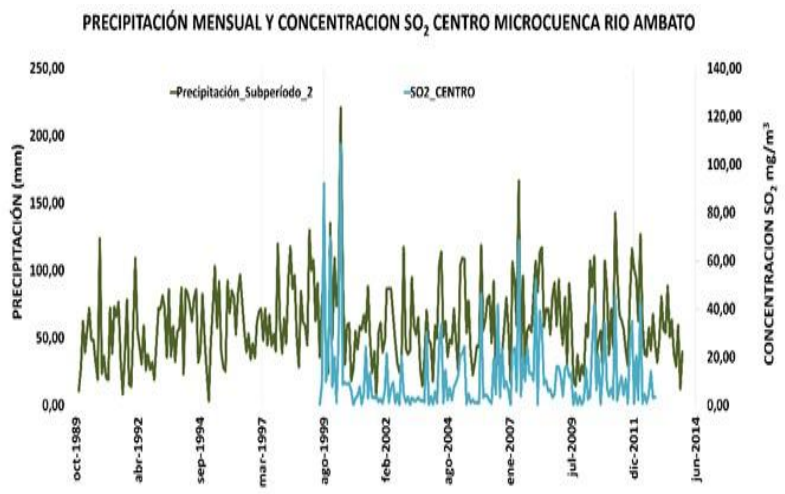

Figure 2: Monthly rainfall- $\mathrm{SO}_{2}$ concentration central Ambato river watershed

Table 2: Precipitation outliers- $\mathrm{SO}_{2}$ concentration north-east, center and south Ambato river watershed

\begin{tabular}{|c|c|c|c|c|c|c|}
\hline \multirow[t]{2}{*}{ FECHA } & \multicolumn{3}{|c|}{ CONCENTRATION SO $\left(\mathrm{mg} / \mathrm{m}^{3}\right)$} & \multicolumn{3}{|c|}{ PRECIPI TATION $(\mathrm{mm})$} \\
\hline & NORTH-EAST & CENTER & SOUTH & NORTH-EAST & CENTER & SOUTH \\
\hline September 1999 & 88,69 & 92,05 & 93,43 & 96,50 & 107,10 & 162,40 \\
\hline December 1999 & 68,54 & 69,72 & 72,09 & 125,80 & 135,00 & 208,50 \\
\hline May 2000 & 96,16 & 108,34 & 112,08 & 215,60 & 220,50 & 349,70 \\
\hline December 2005 & 44,28 & 46,23 & 41,90 & 127,20 & 118,70 & 148,05 \\
\hline August 2006 & & 41,76 & & & 96,30 & \\
\hline June 2007 & & 68.58 & & & 166,50 & \\
\hline February 2008 & & 52,21 & & & 106,80 & \\
\hline June 2010 & & 42,06 & & & 110,50 & \\
\hline April 2011 & 42,78 & 47,49 & & 145,60 & 148,34 & \\
\hline December 2011 & & 37,79 & & & 116,00 & \\
\hline April 2012 & & 43,51 & & & 144,70 & \\
\hline
\end{tabular}

Stochastic model of precipitation for the Ambato river watershed that incorporates the effects of the Tungurahua volcano eruption process

As mentioned methodology in Equation (1) an ARIMAX model, consisting of an exogenous deterministic component $Y v$ and a stochastic component $Y t$ is identified.

\section{Estimating the $Y v$ component}

Initially it is necessary to know if there is a relationship between rainfall and the concentration of $\mathrm{SO}_{2}$ in the Ambato river watershed, we are doing the test of Engle-Granger cointegration. Applying this test to determine the existence of cointegrating regression. For this we identify the time series of precipitation as the dependent variable and the concentration of $\mathrm{SO}_{2}$ calculated as the explanatory variable.

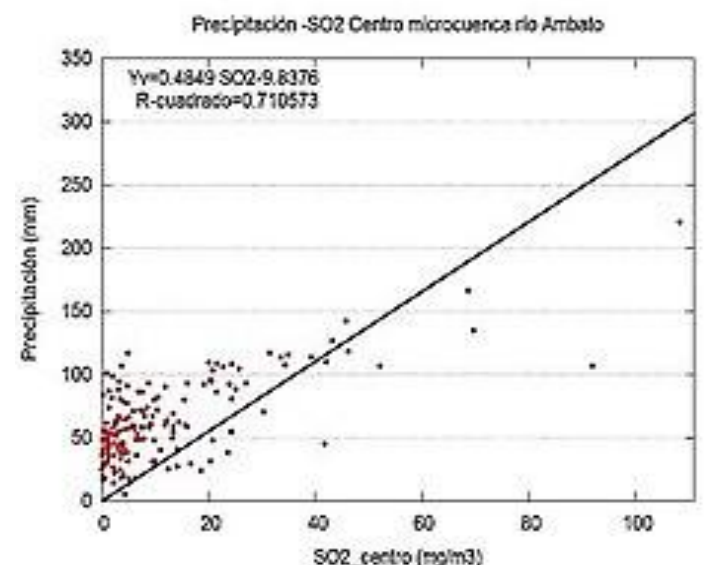

Figure 3: Regression models monthly precipitation seriesconcentration of $\mathrm{SO}_{2}$

The estimated $Y v$ component of the equations are obtained using ordinary least squares models. In Figure 3 the regression models obtained and calculated parameters of the cointegrating component.

Table 3: Statistical test regression mode

\begin{tabular}{|c|c|c|}
\hline Normality residues & Jarque-Bera & $\mathrm{p}$-valor \\
\cline { 2 - 3 } & 2,2465 & 0,3252 \\
\hline \multirow{2}{*}{$\begin{array}{c}\text { Heteroscedasticity } \\
\text { residues }\end{array}$} & $\mathrm{ARCH}$ & $\mathrm{p}$-valor \\
\cline { 2 - 3 } & 17,4555 & 0,1332 \\
\hline Model specification & Reset & $\mathrm{p}$-valor \\
\cline { 2 - 3 } & 0,1534 & 0,858 \\
\hline
\end{tabular}




\section{International Journal of Science and Research (IJSR) \\ ISSN (Online): 2319-7064 \\ Index Copernicus Value (2013): 6.14 | Impact Factor (2014): 5.611}

\section{Estimation of the stochastic component $\boldsymbol{Y t}$}

To apply the methodology ARIMA series of precipitation must be stationary, at least in the broad sense that is constant mean and constant variance. Apply the Dickey Fuller test (ADF) which is a unit root test in a time series.

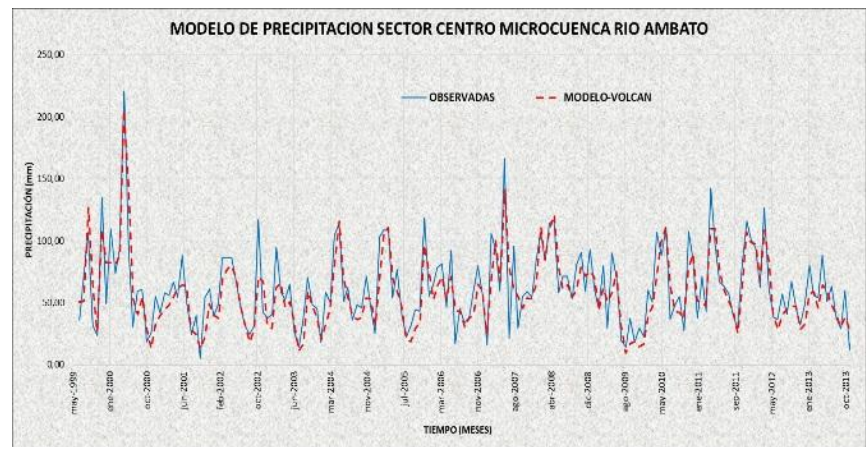

Figure 4: Precipitation patterns obtained for the watershed of the river Ambato

The right model for analysis of precipitation series is an ARIMA $(1,1,0)$. The estimated coefficients is significant $\varnothing 1=-0,4525$ and $<|1|$ in the watershed.

\section{Conclusions}

The interest and concern about the availability of water resources has prompted the development of numerous investigations and scientific studies provide several views on this issue. However, little has been studied about the relationship that may exist between the behavior of precipitation and a volcano eruption process at basin level, even when volcanic activity is considered a sudden and unexpected natural event complicating have the scenario and the conditions for continuous monitoring of the connection between these two natural phenomena.

In the tests, we can say that in the Ambato river watershed changes in precipitation patterns occur during the eruptive process of the Tungurahua volcano. These changes are related to the intensity of the eruption, orientation and height of the ash plume. To eruptive events Volcanic Explosivity Index of falling between two and three $(2 \leq \mathrm{VEI} \leq 3)$ specific and immediate changes are recorded in the series of rainfall throughout the watershed especially in areas near the volcano. To eruptive events Volcanic Explosivity Index lower two ( $\mathrm{VEI} \leq 2)$ gradual changes are recorded in the series of rainfall throughout the watershed especially in areas where the ash content is concentrated by the wind direction.

Volcanic eruptions between September 1999 and May 2000 recorded a $(\mathrm{VEI}=3)$ initiation of the explosive process of volcano eruption generated an ash plume height of 4 to $8 \mathrm{~km}$ above the crater. In May of 2000 in all areas of the watershed point atypical rainfall events are recorded, in the north-east of the watershed point increases in precipitation are marked on values of $285 \%$ compared to the average of the period, the center and south of the watershed increases of $170 \%$ and $249 \%$ respectively.

The model for determining the concentration of $\mathrm{SO}_{2}$ depends on the chemical reactions of sulfur monoxide found in the atmosphere, the results found at the level of the Ambato river watershed are consistent in relation to the shape and direction to take ash clouds at different heights.

Most of $\mathrm{SO}_{2}$ issued by the Tungurahua volcano is located in lower altitudes to 7.000 meters above sea level and concentrations up to $50 \mathrm{ppb}$ in the troposphere. Between September 1999 and May 2000, the beginning of explosive eruption process, $\mathrm{SO}_{2}$ emissions reach 10.000 meters and the calculated concentrations reach $112 \mathrm{ppb}$ in the troposphere.

The model is developed for data in the Ambato river watershed, so it is difficult to say whether the variability of precipitation eruption of the Tungurahua volcano occurs only locally and if the damages are homogeneous in watersheds in the region or if they affect globally. Therefore, it is necessary to extend these studies throughout the area of influence of the Tungurahua volcano.

\section{References}

[1] Ríos, I., and Solera, A. (2015), "Variations in the patterns of precipitation in the watershed of the Ambato River associated with the eruptive process of the Tungurahua volcano in Ecuador." Open Journal of Modern Hydrology, 5, 121-139.

[2] Consejo Provincial de Tungurahua. (2007), "Manejo Ecológicamente Compatible de las Cuencas del Tungurahua." Ambato 115p.

[3] Samaniego, P., (2005), "Los peligros volcánicos asociados con el Tungurahua. Quito".CorporaciónEditora Nacional, ISBN: 9978-84402-3.

[4] Box, G.E.P., and Tiao, G. (1975),"'Intervention Analysis with Applications to economic and Environmental Problems. " Journal of the American Statistical Association 70, 70-79.

[5] Box, G.E.P., and Jenkins, M. (1976), "Time series analysis: Forecasting and control." Journal of the American Statistical Association, 65(332):1509-1526.

[6] Self, S., (2006), "The effects and consequences of very large explosive volcanic eruptions.'Transs. R.Soc, A 2006 364, doi:10.1098/rsta. 2006.1814.

[7] Chapra, S., (2007), "Surface Water Quality Modeling." Waveland Press, Inc, 4180 Long Grove, IL 60047-9580. ISBN 1-57766-605-4.

[8] Montero, R., (2013), "Variables no estacionarias y cointegración.” Documentos de trabajo. Universidad de Granada. España.

[9] Alatorre, J. (2011), "Modelos de series de tiempo." División de desarrollo sostenible y asentamientos humanos CEPAL.

[10] Salas, J., Delleur, D., y Lane, W., (1980),” Applied modeling of hydrologic time series". Water Resources Publications, Littleton, Colorado. 